\title{
Water Resources Response to Climate and Land-Cover Changes in a Semi-Arid Watershed, New Mexico, USA
}

\author{
Joonghyeok $\mathrm{Heo}^{1}$, Jaehyung $\mathrm{Yu}^{2, *}$, John R. Giardino ${ }^{3}$, and Huidae Cho ${ }^{4}$ \\ ${ }^{1}$ UM Energy Institute, University of Michigan, Ann Arbor, MI, USA \\ ${ }^{2}$ Department of Geology and Earth Environmental Sciences, Chungnam National University, Daejeon, South Korea \\ ${ }^{3}$ Department of Geology\&Geophysics and Water Management and Hydrological Sciences Program, \\ Texas A\&M University, TX, USA \\ ${ }^{4}$ Water Resource Engineer, Dewberry Inc., Atlanta, GA, USA
}

Received 27 August 2014, revised 24 March 2015, accepted 24 March 2015

\begin{abstract}
This research evaluates a climate-land cover-water resources interconnected system in a semi-arid watershed with minimal human impact from 1970 - 2009. We found $0.9^{\circ} \mathrm{C}$ increase in temperature and $10.9 \%$ decrease in precipitation. The temperature exhibited a lower increase trend and precipitation showed a similar decrease trend compared to previous studies. The dominant land-cover change trend was grass and forest conversion into bush/shrub and developed land and crop land into barren and grass land. These alterations indicate that changes in temperature and precipitation in the study area may be linked to changes in land cover, although human intervention is recognized as the major land-cover change contributor for the short term. These alterations also suggest that decreasing human activity in the study area leads to developed land and crop land conversion into barren and grass land. Hydrological responses to climate and land-cover changes for surface runoff, groundwater discharge, soil water content and evapotranspiration decreased by 10.2, 10.0, 4.1, and 10.5\%, respectively. Hydrological parameters generally follow similar trends to that of precipitation in semi-arid watersheds with minimal human development. Soil water content is sensitive to land-cover change and offset relatively by the changes in precipitation.
\end{abstract}

Key words: Climate change, Land cover, Semi-arid watershed, Water resources

Citation: Heo, J., J. Yu, J. R. Giardino, and H. Cho, 2015: Water resources response to climate and land-cover changes in a semi-arid watershed, New Mexico, USA. Terr. Atmos. Ocean. Sci., 26, 463-474, doi: 10.3319/TAO.2015.03.24.01(Hy)

\section{INTRODUCTION}

Water is an essential resource for human life on Earth. Water resources are widely used for agriculture, human consumption, recreation, industry and power generation. As a result of changing weather patterns and expanding population water resources are becoming increasingly scarce. Today many parts of the world are facing serious water resources problems, such as water stress and water scarcity. Water resources are the most important factor regulating ecosystem processes in semi-arid climates because these environments are frequently water stressed (IPCC 2007; USGCRP 2009).

Water resources can be affected by climate change. $\mathrm{Nu}-$ merous researchers have demonstrated that climate change intensifies the variations in precipitation and temperature,

\footnotetext{
* Corresponding author

E-mail:jaeyu@cnu.ac.kr
}

which directly influences changes in stream flow, runoff and evapotranspiration (Kundzewicz 2008; Zhang et al. 2012). In addition to climate change, land cover/land change resulting from human activities is considered another factor that directly influences water resources (Ma et al. 2009; Xu et al. 2010). Land cover/land change can alter the hydrological cycle of a region by altering the rates of runoff and infiltration. These changing rates can have a negative impact on the soil water content (He et al. 2009; Dixon and Earls 2012).

Arid climate is one of the five major climate types and can be further classified as semi-arid or desert, based on the Köppen climate classification (Peel et al. 2007; Crosbie et al. 2012). Arid climates currently occupy about $32 \%$ of the land area on Earth, which, incidentally, is the largest climate zone. This climate type is associated mostly with the midlatitude western, wind belts and restricted to the western parts of North America and South America, the northern 
part of Africa, the northwestern part of Asia and the central part of Australia. Although arid climates are generally considered to sparsely populated areas, major populations located in arid climates are present in cities such as, Tucson, Phoenix, Cairo, and Dubai. Fraedrich et al. (2001) estimated that the spatial extent of arid climates has increased by $1.0 \%$ during the period 1955 - 1995, and its spatial extent will continue to increase in the future.

Numerous studies have been undertaken to estimate the impact of various entities on water resources in semi-arid climates. Previous studies have suggested that watersheds with certain levels of human intervention show decreasing trends in groundwater quantity $(15 \%)$, as precipitation decreases by $5-10 \%$ and temperature increases by $2-2.5^{\circ} \mathrm{C}$ during the 35 - 50 years of observation (Rosenberg et al. 1999; Séguis et al. 2004; Jarsjö et al. 2012; Montenegro and Ragab 2012). To clearly understand the impact of climate change on water resources in a region, the impact of landcover change resulting from human impact must be excluded from this research. Although previous research has made advances in understanding the impact of climate change on water resources, no studies, to date, have clearly focused on the impact of "natural" climate change (i.e., no anthropogenic intervention) on water resources in a semi-arid watershed. The reason previous research did not accomplish this was because their study areas all contained significant amounts of developed land-cover. Moreover, previous research used only one representative land-cover datum in the simulations of long-term change. Therefore, natural variations and human interventions in the land-cover-change equation were not appropriately considered in previous research.

We selected a semi-arid watershed with minimal human habitation to factor out anthropogenic intervention to address the above concern. Three land-cover data sets, representing sub-periods of observation, are employed to simulate a more realistic response of water resources to changing conditions. The impact of climate and land-cover changes on water resources can be better defined rather than simply observing one representative land-cover datum. The objective of this study is to evaluate the water resources response to changes in climate and land-cover in a semi-arid watershed that has minimal anthropogenic intervention. The time-frame for the study is the period 1970 - 2009.

\section{STUDY AREA}

The study area is located in northeast New Mexico, USA, which is part of the Upper Canadian River Basin (Fig. 1). It has a total area of $5289.9 \mathrm{~km}^{2}$ and is located within Hydrologic Unit Code (HUC) 11080007. The study area extends across three counties of New Mexico; Harding, Union and Colfax. The study area elevation ranges from $1163-2551 \mathrm{~m}$. The study area land cover consists mainly of vegetation, bare soil and water. Because natural areas (i.e., vegetation, bare soil, and water) account for about $98 \%$ of the total area this study area was selected to evaluate the impact of climate on water resources where human impact is minimal.

The study area is predominantly semi-arid. The annual mean temperature is $11.3^{\circ} \mathrm{C}$ and the annual total precipitation is $406.1 \mathrm{~mm}$. The annual mean temperature and annual total precipitation are based on data from four climatic stations: Bueyeros, Mosquero, Pasamonte, and Roy. Four climate stations and one gauging station are located in the study area to provide long-term climatic and hydrological data with a relatively dense observation network (Fig. 1).

\section{MATERIAL AND METHODS}

\subsection{Data}

Precipitation and temperature data collected by the $\mathrm{Na}-$ tional Climate Data Center (NCDC) of the National Oceanic and Atmospheric Administration (NOAA) and United States Department of Agriculture (USDA) were used in our study. The annual total precipitation and annual mean temperature were calculated from daily data and used to analyze changes in temperature and precipitation from 1970 - 2009. Stream flow data were obtained from the National Water Information System (NWIS) of the US Geological Service (USGS). The one gauge station (07226500) in the study area has provided continuous daily data from 1970 - 2009 and is located at the outlet of the upper Canadian River watershed. Soil data for the study area was obtained from the State Soil Geographic (STATSGO) database. The STATSGO is a digital soil map created in 1994 by the Natural Resources Conservation Service (NRCS). In addition to the above data sets, a Digital Elevation Model (DEM) with a 30-m spatial

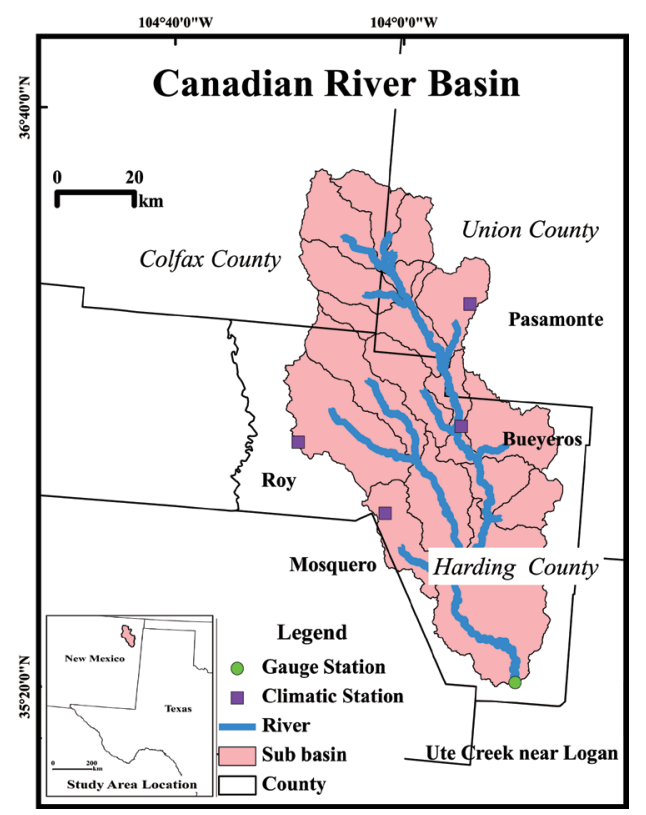

Fig. 1. Location map of the study area. 
resolution was obtained from the Earth Resource Observation and Sciences (EROS) of the USGS.

The land-cover data were generated to simulate three separate temporal periods for the study area for use in the Soil and Water Assessment Tool (SWAT) models. The three temporal periods represent: 1970 - 1989, 1990 - 1999, and 2000 - 2009. Land Use and Land Cover (LULC) is historical data derived from USGS aerial photography taken during the 1970s - 1980s period. The National Land Cover Dataset (NLCD) 1992 was created in the early 1990s using Landsat Thematic Mapper (TM) data. The NLCD2001 is based on the early 2000s Landsat Enhanced Thematic Mapper+ (ETM+) data. The NLCD2001 has been updated in the version NLCD2006 using the Landsat ETM+. The land-cover data sets have different sub-category legends used in the classification. To maintain land-cover classification consistency the land-cover data are reclassified into the following seven classes: (1) grass, (2) bush/shrub, (3) forest, (4) developed land, (5) barren land, (6) water, and (7) crop land. The developed land is defined as areas where constructed materials, such as asphalt, concrete and buildings, account for greater than $30 \%$ of the total cover (Wickham et al. 2004). The landcover change comparison is applied to quantitatively detect aerial change in land-cover class (i.e., which land-cover class is changing to the other type of land-cover class). This pro- cess involves a pixel to pixel comparison of different landcover data representing two different time periods in a GIS environment (Long et al. 2007; Tsegaye et al. 2010).

\subsection{SWAT Model}

SWAT is a hydrologic modeling tool designed to evaluate surface runoff, soil water content, groundwater discharge, and evapotranspiration. SWAT has proven to be an effective tool for assessing water resources and land-cover changes over a wide range of scales (Zhang et al. 2010). Table 1 lists the eleven parameters used in the calibration process from the SWAT models. They were selected based on the list in SWAT calibration tool and extensive literature review (Zhang et al. 2009; Mosbahi et al. 2014). For this study, three SWAT models were built with three simulation periods; period 1 (LULC with weather data from 1970 - 1989), period 2 (NLCD1992 with weather data from 1990 - 1999), and period 3 (NLCD2001 with weather data from 2000 - 2009). We employed three different land-cover data representing each period to simulate the most realistic hydrological model because land-cover data play an important factor in water resources response (Table 2). The SWAT models were calibrated and validated for the first and second half of each period, respectively. We simulated three SWAT models independently

Table 1. Eleven parameters used in the SWAT models (in alphabetic order).

\begin{tabular}{ccccc}
\hline Name & Description & Range & Calibrated value & Process \\
\hline ALPHA_BF & Base flow alpha factor (days) & $0-1$ & 0.62 & Groundwater \\
CANMX & Maximum canopy storage & $0-10$ & 3.89 & Runoff \\
EPCO & Plant evaporation compensation factor & $0-1$ & 0.88 & Evapotranspiration \\
ESCO & Soil evaporation compensation factor & $0-1$ & 0.89 & Evapotranspiration \\
GW_DELAY & Groundwater delay (days) & $0-50$ & 13.1 & Groundwater \\
GW_REVAP & Groundwater re-evaporation coefficient & $0.02-0.2$ & 0.03 & Groundwater \\
GWQMN & Threshold depth of water in shallow aquifer required for return flow to occur (mm) & $0-5000$ & 900 & Soil \\
RCHRG_DP & Groundwater recharge to deep aquifer (fraction) & $0-1$ & 0.82 & Groundwater \\
REVAPMN & Threshold depth of water in shallow aquifer for re-evaporation to occur (mm) & $0-500$ & 20.46 & Groundwater \\
SOL_AWC & Available water capacity of the soil layer (mm mm ${ }^{-1}$ soil) & $0-1$ & 0.14 & Soil \\
SURLAG & Surface runoff lag coefficient & $0-10$ & 6.17 & Runoff \\
\hline
\end{tabular}

Note: Calibrated value indicates a representative value, which takes an average of the three study periods in all sub-basins.

Table 2. Summary of calibration and validation values in three simulations from the SWAT models.

\begin{tabular}{c|c|c|cc|cc}
\hline \multirow{2}{*}{ Simulations } & \multirow{2}{*}{ Years } & \multirow{2}{*}{ Land cover data } & \multicolumn{2}{|c|}{ Calibration } & \multicolumn{2}{|c}{ Validation } \\
\cline { 4 - 7 } & & & NSE & $\mathbf{R}^{2}$ & NSE & $\mathbf{R}^{2}$ \\
\hline Period 1 & $1970-1989$ & LULC & 0.71 & 0.73 & 0.74 & 0.76 \\
Period 2 & $1990-1999$ & NLCD1992 & 0.66 & 0.67 & 0.68 & 0.69 \\
Period 3 & $2000-2009$ & NLCD2001 & 0.68 & 0.69 & 0.69 & 0.70 \\
\hline
\end{tabular}

Note: NSE: Nash-Sutcliffe Efficiency coefficient; $R^{2}$ : coefficient of determination. 
using Isolated-Speciation-based Particle Swarm Optimization (Cho et al. 2011), which was successfully applied to a climate change study (Heo et al. 2015), uncertainty analysis (Cho and Olivera 2014), and stochastic rainfall generation (Kim et al. 2013). Table 2 shows the summary of calibration and validation values in three simulations from the SWAT models. The observed stream flow and simulated stream flow are plotted in Fig. 2. Moriasi et al. (2007) suggested that Nash-Sutcliffe Efficiency (NSE) values $>0.75$ are considered excellent, values $>0.65$ are considered good, and values $>0.5$ are considered satisfactory for hydrological model evaluation. They further concluded that $\mathrm{R}^{2}$ values $>0.5$ are regarded as acceptable for model simulation. The calibration and validation values of this study ranged from $0.66-0.76$, which indicates good and acceptable simulations.

\section{RESULTS}

\subsection{Changes in Climate}

The annual mean temperature shows an increasing trend whereasthe annual total precipitation shows a decreasing trend for the study area during the observation period (Figs. 3a, b). The annual mean temperature increased by $0.9^{\circ} \mathrm{C}$ with a slope of 0.029 and the annual mean temperature for periods 1,2 , and 3 were $11.0,11.3$, and $11.9^{\circ} \mathrm{C}$, respectively (Table 3 ). The temporal pattern shows a mixed trend of both deceasing and increasing temperatures, where period 1 showed a decreasing pattern and periods 2 and 3 showed an increasing pattern (Fig. 3a). Previous research (Guo et al. 2005; Abdulla et al. 2009; Wu et al. 2012) found a temperature increase ranging from $1.5-2.5^{\circ} \mathrm{C}$ in semi-arid climates over

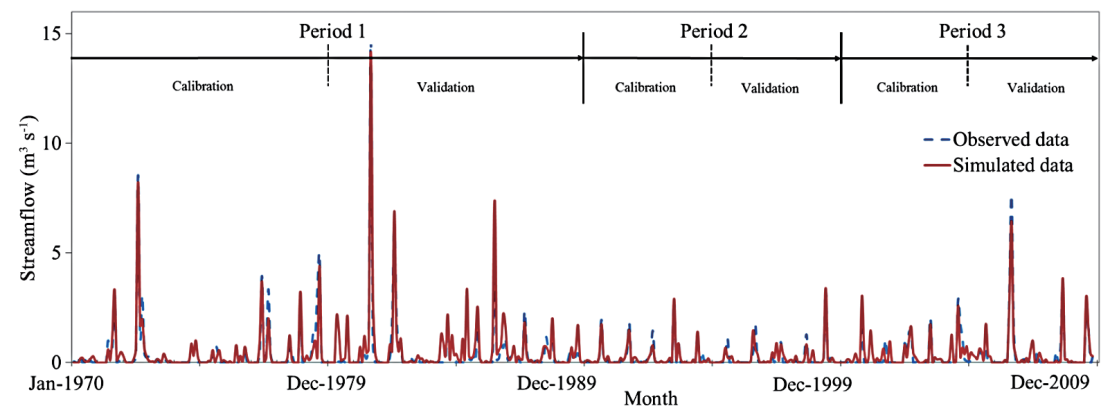

Fig. 2. Monthly observed stream flow and simulated stream flow from 1970 - 2009.

(a)

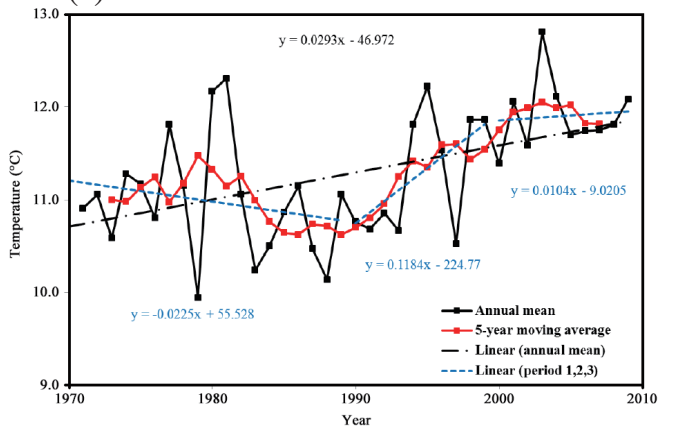

(b)

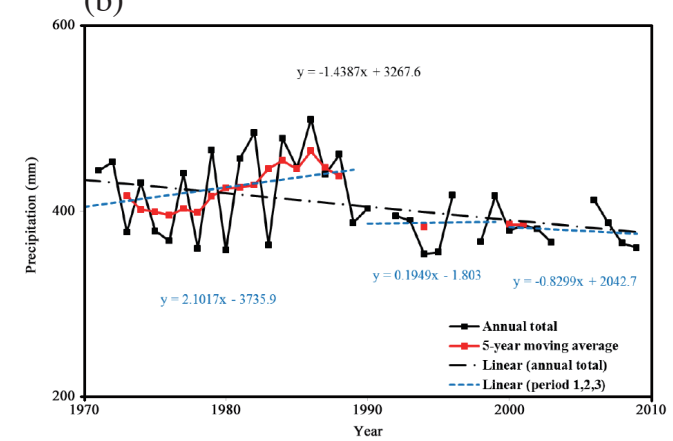

Fig. 3. Historical temperature and precipitation changes during 1970 - 2009.

Table 3. Annual mean temperature and annual total precipitation for three time periods.

\begin{tabular}{l|rrrrrr|rrrrrc}
\hline & \multicolumn{5}{|c|}{ Temperature $\left({ }^{\circ} \mathbf{C}\right)$} & \multicolumn{5}{c}{ Precipitation $(\mathbf{m m})$} \\
\cline { 2 - 12 } & Mean & MIN & MAX & STD & CV & SIG & Mean & MIN & MAX & STD & CV & SIG \\
\hline Period 1 (1970 - 1989) & 11.0 & 9.9 & 12.3 & 0.6 & 0.06 & 0.40 & 425.5 & 357.5 & 498.7 & 46.9 & 0.11 & 0.36 \\
Period 2 (1990 - 1999) & 11.3 & 10.5 & 12.2 & 0.6 & 0.06 & 0.21 & 386.9 & 353.5 & 417.1 & 25.6 & 0.07 & 1.00 \\
Period 3 (2000 - 2009) & 11.9 & 11.4 & 12.3 & 0.3 & 0.02 & 0.41 & 379.2 & 360.0 & 411.5 & 16.4 & 0.04 & 0.39 \\
Overall (1970 - 2009) & 11.3 & 9.9 & 12.8 & 0.7 & 0.06 & 0.01 & 406.1 & 353.5 & 498.7 & 42.7 & 0.11 & 0.04 \\
\hline
\end{tabular}

Note: MIN: minimum, MAX: maximum, STD: standard deviation, CV: coefficient of variation, and SIG: significance test (p-value, trends statistically significant at p-value $<0.05$ ). 
the observation period. Considering the relatively long observation period of forty years in the current study, the temperature increase appears to show a moderate increase.

The annual total precipitation decreased by $10.9 \%$ and had a decreasing trend with an overall slope of -1.439 during the forty-year period (Fig. 3b). The annual total precipitation for periods 1, 2, and 3 were 425.5, 386.9, and $379.2 \mathrm{~mm}$, respectively (Table 3 ). The annual total precipitation for periods 1 and 2 showed an increasing trend whereas period 3 had a decreasing trend (Fig. 3b). Previous studies reported $5-10 \%$ decrease in precipitation for other semi-arid climatic locations (Guo et al. 2005; Abdulla et al. 2009; Jarsjö et al. 2012). Compared to these previous studies the study area shows a relatively similar trend in precipitation with a $10.9 \%$ decrease.

Table 3 shows the trends for temperature and precipitation during the observation period. The coefficient of variation for the annual mean temperature is 0.06 for periods 1 and 2 , and 0.02 for period 3 . This last value indicates that period 3 had the smallest variation in annual mean temperature and shows relatively even distribution. The significance test shows trends in the overall periods which are statistically significant at the 0.05 level. However, no significant trends were detected for sub-periods 1,2 , and 3 . These re- sults seem reasonable when considered in the context that global temperature and precipitation increased by $0.7^{\circ} \mathrm{C}$ and $5 \%$ during the last one hundred years. However, different patterns were shown in each period with regard to warming (1901 - 1940: greenhouse gas, 1966 - 2000: El Niño and greenhouse gas) and cooling (1941 - 1965) (IPCC 2007).

\subsection{Changes in Land Cover}

Figure 4 displays the historical land-cover maps for the study area. The areas and percentage of land-cover types during the three different time periods are shown in Table 4. The land-cover change comparison is also used to identify the pattern of quantitative change in each type of land cover (Table 5).

\subsubsection{Changes in Land Cover from 1970s/1980s to 1990s}

In the $1970 \mathrm{~s} / 1980 \mathrm{~s}$ grass accounted for $92.5 \%$ of the study area, followed by forest (3.9\%), developed land $(1.2 \%)$, crop land $(1.2 \%)$, barren land $(0.8 \%)$, bush/shrub $(0.3 \%)$, and water $(0.1 \%)$ (Table 4$)$. Because almost $98 \%$ of the area is either natural vegetation or barren land, human

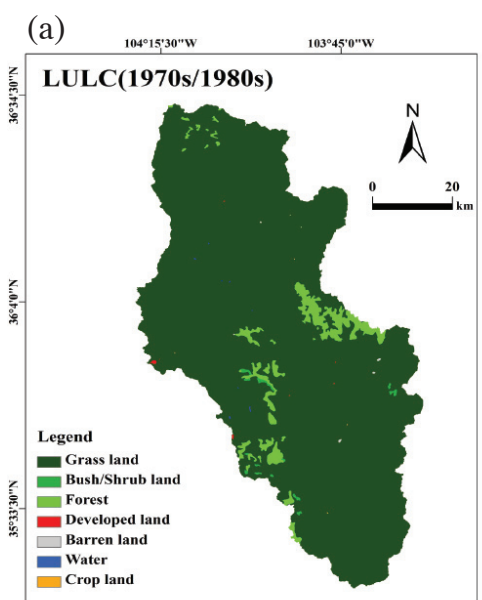

(c)

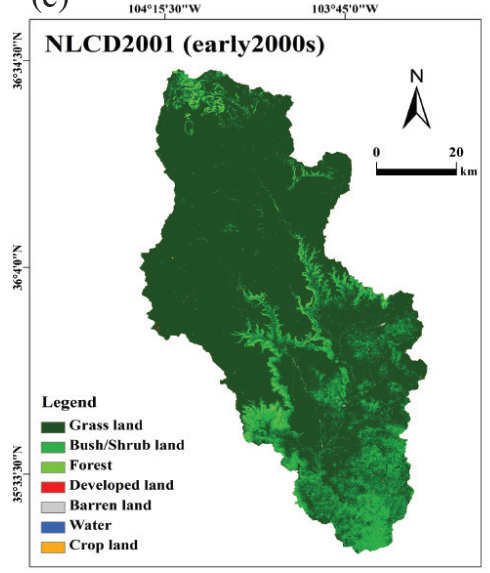

(b)

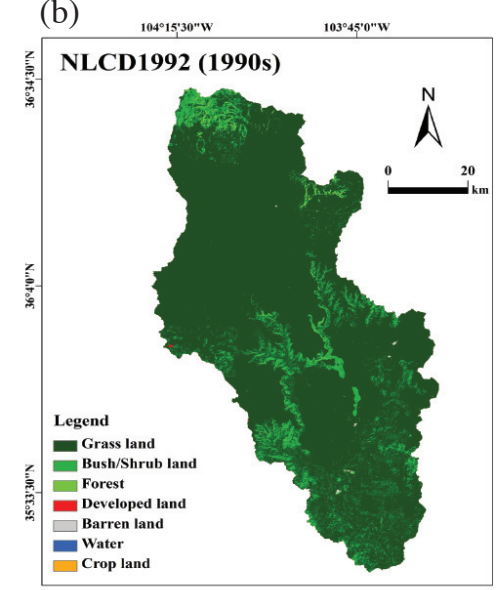

(d)

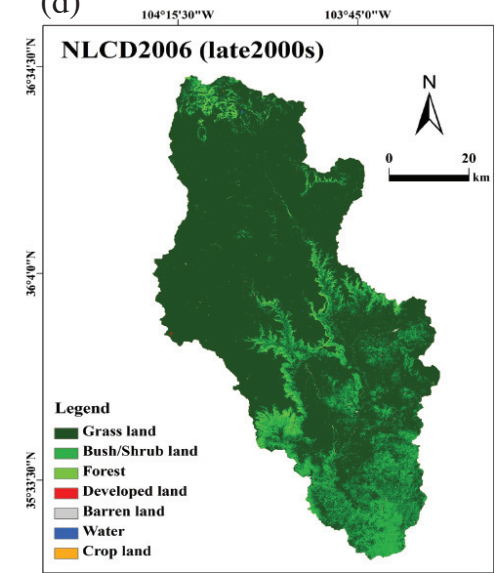

Fig. 4. Historical land-cover maps in the study area; (a) LULC, (b) NLCD1992, (c) NLCD2001, and (d) NLCD2006. 
Table 4. The area of each land-cover type based on historical land-cover maps (unit: $\mathrm{km}^{2}$ ).

\begin{tabular}{c|ccccccc|c}
\hline & G & BS & F & D & B & W & C & Total \\
\hline \multirow{2}{*}{ LULC } & 4893.7 & 15.3 & 205.8 & 63.5 & 41.8 & 7.4 & 62.4 & 5289.9 \\
& $(92.5 \%)$ & $(0.3 \%)$ & $(3.9 \%)$ & $(1.2 \%)$ & $(0.8 \%)$ & $(0.1 \%)$ & $(1.2 \%)$ & $(100 \%)$ \\
\multirow{4}{*}{ NLCD1992 } & 4809.5 & 246.0 & 80.4 & 59.3 & 46.0 & 7.4 & 41.3 & 5289.9 \\
& $(90.9 \%)$ & $(4.7 \%)$ & $(1.5 \%)$ & $(1.1 \%)$ & $(0.9 \%)$ & $(0.1 \%)$ & $(0.8 \%)$ & $(100 \%)$ \\
\multirow{4}{*}{ NLCD2001 } & 4585.7 & 513.8 & 73.5 & 31.2 & 74.1 & 6.3 & 5.3 & 5289.9 \\
& $(86.7 \%)$ & $(9.7 \%)$ & $(1.4 \%)$ & $(0.6 \%)$ & $(1.4 \%)$ & $(0.1 \%)$ & $(0.1 \%)$ & $(100 \%)$ \\
\multirow{3}{*}{ NLCD2006 } & 4538.1 & 561.4 & 73.5 & 31.2 & 74.1 & 6.3 & 5.3 & 5289.9 \\
& $(85.8 \%)$ & $(10.6 \%)$ & $(1.4 \%)$ & $(0.6 \%)$ & $(1.4 \%)$ & $(0.1 \%)$ & $(0.1 \%)$ & $(100 \%)$ \\
\hline \multirow{2}{*}{ Changes } & -355.6 & 546.1 & -132.3 & -32.3 & 32.3 & -0.9 & -57.1 & \\
& $(-6.7 \%)$ & $(10.3 \%)$ & $(-2.5 \%)$ & $(-0.6 \%)$ & $(0.6 \%)$ & $(0.0 \%)$ & $(-1.1 \%)$ & \\
\hline
\end{tabular}

Note: G: grass, BS: bush/shrub, F: forest, D: developed land, B: barren land, W: water, and C: crop land.

Table 5. The comparison of land-cover change between the three different time periods; (a) LULC(1970s/1980s) NLCD1992, and (b) NLCD1992 - NLCD2001 (unit: km²).

\begin{tabular}{|c|c|c|c|c|c|c|c|c|c|}
\hline \multirow{2}{*}{\multicolumn{2}{|c|}{ (a) }} & \multicolumn{7}{|c|}{ NLCD1992 } & \multirow{2}{*}{$\begin{array}{c}\text { LULC } \\
\text { Total }\end{array}$} \\
\hline & & $\mathbf{G}$ & BS & $\mathbf{F}$ & D & B & W & $\mathbf{C}$ & \\
\hline \multirow{7}{*}{ LULC } & G & $\begin{array}{c}4788.4 \\
(97.8 \%)\end{array}$ & $\begin{array}{c}105.3 \\
(2.2 \%)\end{array}$ & & & & & & $\begin{array}{c}4893.7 \\
(100.0 \%)\end{array}$ \\
\hline & BS & & $\begin{array}{c}15.3 \\
(100.0 \%)\end{array}$ & & & & & & $\begin{array}{c}15.3 \\
(100.0 \%)\end{array}$ \\
\hline & $\mathbf{F}$ & & $\begin{array}{c}125.4 \\
(60.9 \%)\end{array}$ & $\begin{array}{c}80.4 \\
(39.1 \%)\end{array}$ & & & & & $\begin{array}{c}205.8 \\
(100.0 \%)\end{array}$ \\
\hline & D & & & & $\begin{array}{c}59.3 \\
(93.4 \%)\end{array}$ & $\begin{array}{c}4.2 \\
(6.6 \%)\end{array}$ & & & $\begin{array}{c}63.5 \\
(100.0 \%)\end{array}$ \\
\hline & B & & & & & $\begin{array}{c}41.8 \\
(100.0 \%)\end{array}$ & & & $\begin{array}{c}41.8 \\
(100.0 \%)\end{array}$ \\
\hline & $\mathbf{W}$ & & & & & & $\begin{array}{c}7.4 \\
(100.0 \%)\end{array}$ & & $\begin{array}{c}7.4 \\
(100.0 \%)\end{array}$ \\
\hline & C & $\begin{array}{c}21.1 \\
(33.8 \%)\end{array}$ & & & & & & $\begin{array}{c}41.3 \\
(66.2 \%)\end{array}$ & $\begin{array}{c}62.4 \\
(100.0 \%)\end{array}$ \\
\hline \multicolumn{2}{|c|}{$\begin{array}{c}\text { NLCD1992 } \\
\text { Total } \\
\end{array}$} & $\begin{array}{c}4809.5 \\
(100.0 \%) \\
\end{array}$ & $\begin{array}{c}246.0 \\
(100.0 \%) \\
\end{array}$ & $\begin{array}{c}80.4 \\
(100.0 \%) \\
\end{array}$ & $\begin{array}{c}59.3 \\
(100.0 \%) \\
\end{array}$ & $\begin{array}{c}46.0 \\
(100.0 \%) \\
\end{array}$ & $\begin{array}{c}7.4 \\
(100.0 \%) \\
\end{array}$ & $\begin{array}{c}41.3 \\
(100.0 \%) \\
\end{array}$ & 5289.9 \\
\hline \multirow{2}{*}{\multicolumn{2}{|c|}{ (b) }} & \multicolumn{7}{|c|}{ NLCD2001 } & NLCD1992 \\
\hline & & G & BS & $\mathbf{F}$ & D & B & W & C & Total \\
\hline \multirow{7}{*}{$\begin{array}{c}\text { NLCD } \\
1992\end{array}$} & G & $\begin{array}{c}4548.6 \\
(94.6 \%)\end{array}$ & $\begin{array}{c}260.9 \\
(5.4 \%)\end{array}$ & & & & & & $\begin{array}{c}4809.5 \\
(100.0 \%)\end{array}$ \\
\hline & BS & & $\begin{array}{c}246.0 \\
(100.0 \%)\end{array}$ & & & & & & $\begin{array}{c}246.0 \\
(100.0 \%)\end{array}$ \\
\hline & $\mathbf{F}$ & & $\begin{array}{c}6.9 \\
(8.6 \%)\end{array}$ & $\begin{array}{c}73.5 \\
(91.4 \%)\end{array}$ & & & & & $\begin{array}{c}80.4 \\
(100.0 \%)\end{array}$ \\
\hline & D & & & & $\begin{array}{c}31.2 \\
(52.6 \%)\end{array}$ & $\begin{array}{c}28.1 \\
(47.4 \%)\end{array}$ & & & $\begin{array}{c}59.3 \\
(100.0 \%)\end{array}$ \\
\hline & B & & & & & $\begin{array}{c}46.0 \\
(100.0 \%)\end{array}$ & & & $\begin{array}{c}46.0 \\
(100.0 \%)\end{array}$ \\
\hline & W & $\begin{array}{c}1.1 \\
(14.9 \%)\end{array}$ & & & & & $\begin{array}{c}6.3 \\
(85.1 \%)\end{array}$ & & $\begin{array}{c}7.4 \\
(100.0 \%)\end{array}$ \\
\hline & C & $\begin{array}{c}36.0 \\
(87.2 \%) \\
\end{array}$ & & & & & & $\begin{array}{c}5.3 \\
(12.8 \%) \\
\end{array}$ & $\begin{array}{c}41.3 \\
(100.0 \%) \\
\end{array}$ \\
\hline \multicolumn{2}{|c|}{$\begin{array}{c}\text { NLCD2001 } \\
\text { Total }\end{array}$} & $\begin{array}{c}4585.7 \\
(100.0 \%)\end{array}$ & $\begin{array}{c}513.8 \\
(100.0 \%)\end{array}$ & $\begin{array}{c}73.5 \\
(100.0 \%)\end{array}$ & $\begin{array}{c}31.2 \\
(100.0 \%)\end{array}$ & $\begin{array}{c}74.1 \\
(100.0 \%)\end{array}$ & $\begin{array}{c}6.3 \\
(100.0 \%)\end{array}$ & $\begin{array}{c}5.3 \\
(100.0 \%)\end{array}$ & 5289.9 \\
\hline
\end{tabular}

Note: G: grass, BS: bush/shrub, F: forest, D: developed land, B: barren land, W: water, and C: crop land. 
intervention in the area is considered to be only about $2 \%$. During that twenty-year period a decrease in forest and grass and an increase in bush/shrub occurred. As a result of forest and grass conversion into bush/shrub the total bush/shrub area increased from 15.3 - $246.0 \mathrm{~km}^{2}$ (Table 5a). Evident changes in human activities occurred from the 1970s/1980s to 1990s. In the 1970s/1980s developed land and crop land were the third and fourth major land covers occupying 63.5 and $62.4 \mathrm{~km}^{2}$ of the study area, respectively. In the $1990 \mathrm{~s}$ $6.6 \%$ of developed land was converted into barren land and $33.8 \%$ of crop land was converted into grass, indicating a decrease in human activities in the study area.

\subsubsection{Changes in Land Cover from 1990s to 2000s}

Compared to the previous period grass conversion into bush/shrub is more significant (i.e., $260.9 \mathrm{~km}^{2}$ ) whereas forest conversion into bush/shrub is less significant $\left(6.9 \mathrm{~km}^{2}\right)$ (Table 5b). This increase in bush/shrub in terms of area from 246.0 - $513.8 \mathrm{~km}^{2}$ occurred during a ten-year period. As human activities decreased, $47.4 \%$ of the developed land was converted into barren land and $87.2 \%$ of crop land was converted into grass, which is significantly larger compared to the previous period. Additionally, $14.9 \%$ of the sauce water was converted into grass land. From the early 2000 s to the late 2000s additional grass land was converted into bush/ shrub land $\left(47.6 \mathrm{~km}^{2}\right)$ (Table 4).

\subsection{Change in Water Resources}

The components simulated by SWAT were surface runoff, groundwater discharge, soil water content and evapotranspiration (Fig. 5 and Table 6). Table 7 summarizes the proportions of each component compared to the annual total precipitation. It is important to note, unfortunately, that
SWAT does not provide a means to simulate the change in storage (in soil or bedrock). For this reason the mass balance equation for the hydrological cycle was used to calculate the change in water storage. The mass balance equation for the hydrological cycle is expressed as:

$\mathrm{P}=\mathrm{R}+\mathrm{G}+\mathrm{S}+\mathrm{ET}+\Delta \mathrm{W}$

where $P$ is precipitation, $R$ is surface runoff, $G$ is groundwater discharge, $\mathrm{S}$ is soil water content, $\mathrm{ET}$ is evapotranspiration and $\Delta \mathrm{W}$ is the change in storage (Keating et al. 2002; Scanlon et al. 2002; Sharda et al. 2006) .

\subsubsection{Surface Runoff}

The annual total surface runoff ranged from 21.216 - $19.052 \mathrm{~mm}$ (Table 6), which accounted for $5.1 \%$ of the

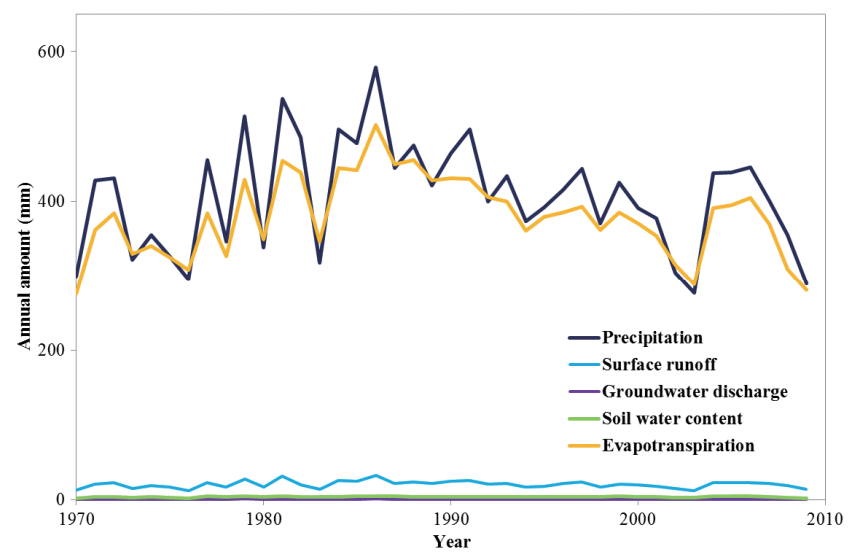

Fig. 5. Annual total amounts of surface runoff, groundwater discharge, soil water content and evapotranspiration derived from a SWAT model for the period $1970-2009$.

Table 6. Annual amount of each hydrological component as derived by the SWAT (unit: mm).

\begin{tabular}{c|cccc}
\hline & Surface runoff & Groundwater discharge & Soil water content & Evapotranspiration \\
\hline Period 1 (1970 - 1989) & 21.216 & 0.850 & 4.012 & 388.573 \\
Period 2 (1990 - 1999) & 21.282 & 0.775 & 4.008 & 393.113 \\
Period 3 (2000 - 2009) & 19.052 & 0.765 & 3.848 & 347.778 \\
\hline Changes & $-10.2 \%$ & $-10.0 \%$ & $-4.1 \%$ & $-10.5 \%$ \\
\hline
\end{tabular}

Table 7. Proportion of each hydrological component to total precipitation (unit: \%).

\begin{tabular}{c|cccc}
\hline & Surface runoff & Groundwater discharge & Soil water content & Evapotranspiration \\
\hline Period 1 (1970 - 1989) & 5.1 & 0.2 & 1.0 & 93.2 \\
Period 2 (1990 - 1999) & 5.1 & 0.2 & 1.0 & 93.3 \\
Period 3 (2000 - 2009) & 5.1 & 0.2 & 1.0 & 93.6 \\
\hline Overall & 5.1 & 0.2 & 1.0 & 93.4 \\
\hline
\end{tabular}


annual total precipitation for each of the three periods (Table 7). The proportion to the annual total precipitation was relatively stable, with a $10.2 \%$ decrease in surface runoff occurring during the three periods along with a $10.9 \%$ decrease in precipitation. Given the climatic condition of an increasing trend in temperature and a decreasing trend in precipitation, surface runoff follows the decreasing trend in precipitation with a relatively stable contribution in terms of the proportion to precipitation.

\subsubsection{Groundwater Discharge}

As the annual total precipitation decreased in the study area, the annual total groundwater discharge also decreased during the forty-year period. The annual total groundwater discharge was $0.850 \mathrm{~mm}$ in period $1,0.775 \mathrm{~mm}$ in period 2, and $0.765 \mathrm{~mm}$ in period 3 (Table 6). Groundwater discharge decreased by $10.0 \%$ from $1970-2009$ for the study area. The changes in groundwater discharge does not appear to play an important role in the study area hydrological system as the total amount of groundwater discharge accounts for only $0.2 \%$.

\subsubsection{Soil Water Content}

The annual total soil water content for periods 1,2 , and 3 were $4.012,4.008$, and $3.848 \mathrm{~mm}$, respectively, which decreased by $4.1 \%$ (Table 6 ). The soil water content proportion to the annual total precipitation, however, stayed at $1.0 \%$ during the forty years (Table 7). Given a $10.9 \%$ decrease in precipitation along with a change in temperature, the changes in soil water content appear to have been minimally affected by the decrease in precipitation. This finding is contrary to the general negative relationship between precipitation and soil water content, which may infer additional parameters other than climate, such as land-cover changes.

\subsubsection{Evapotranspiration}

Evapotranspiration of $388.573 \mathrm{~mm}$ occurred in period $1,393.113 \mathrm{~mm}$ in period 2, and $347.778 \mathrm{~mm}$ in period 3 (Table 6). As precipitation decreased by $10.9 \%$, evapotranspiration decreased by $10.5 \%$, which is a relatively similar rate of decrease to that for precipitation. The evapotranspiration accounted for $93.4 \%$ of the precipitation received (Table 7). As the study area experienced an increase in temperature and a decrease in precipitation, the evapotranspiration rate decreased during the observation period. Although temperature is considered to be a major factor controlling evapotranspiration, evapotranspiration in our study area tracked the precipitation trend.

\section{DISCUSSION}

\subsection{Changes in Climate}

From 1970 - 2009 a $0.9^{\circ} \mathrm{C}$ increase in temperature from $11.0-11.9^{\circ} \mathrm{C}$ occurred with a $10.9 \%$ decrease in precipitation from 425.5 - $379.2 \mathrm{~mm}$. Previous studies for semi-arid climates confirmed that temperature increases with increased $\mathrm{CO}_{2}$, air pollution and expanded human population and development (Claessens et al. 2006; IPCC 2007). Local temperature variations can be enhanced by land-cover change brought about by human impacts. Developed land has a relatively high heat capacity and albedo, which can contribute to temperature increases (Seto and Shepherd 2009; Chuai et al. 2013). Additionally, USGCRP (2009) demonstrated that global temperature can be slowly increased without human impacts based on the Global Climate Models (GCMs). This study focused on the changes in temperature and precipitation in a semi-arid watershed that has minimal human activities. Temperature increased by $0.9^{\circ} \mathrm{C}$ for a semi-arid watershed with about $1 \%$ developed land. Previous studies for a semiarid climate reported temperature increases of $1.5-2.5^{\circ} \mathrm{C}$ with a considerable amount of developed land. The present study reveals a lower magnitude in temperature increase. This study infers that temperature variation in a semi-arid climate is highly likely with a slightly increasing trend, which results from natural conditions when human impact is removed.

Precipitation is governed primarily by the availability of moisture, land-cover change and atmospheric circulation patterns (Ziegler et al. 2005; USGCRP 2009; Zhang et al. 2012). Human activities also influence precipitation variations at the global scale by producing air pollutants, greenhouse gasses and aerosols (IPCC 2007). At the local scale, land-cover change plays an important role in affecting precipitation variations. Human activity involves the removal of vegetation, increase in developed land and a resulting increase in impervious areas, which affects precipitation variation because of decreased soil infiltration and evapotranspiration rates (Hamdi et al. 2011). The study area experienced a decrease in precipitation from $425.5-379.2 \mathrm{~mm}$ during the forty-year study period; accounting for $10.9 \%$ decrease. Precipitation in the study area does not show a notable difference when compared to studies of other semi-arid climates. This explains that precipitation is not significantly affected by land-cover change. We think this suggests that the decrease in precipitation in our study area is a global phenomenon being experienced also by other semi-arid climates, regardless of land-cover patterns.

\subsection{Changes in Land Cover}

From 1970 - 2009 about $10 \%$ of the study area was converted into bush/shrub land and about $2 \%$ of the study area was converted from developed and crop land into barren and grass land. In general climate does have an influence on the types of vegetation and the distribution (Lenihan et al. 2003; Brümmer et al. 2012). Previous studies reported an increase in bush/shrub $(10-11 \%)$ and a decrease in grass 
(7 - 21\%) and forest (8 - 21.5\%) for semi-arid climates where the changes in vegetation were caused mainly by variability in precipitation, drought, natural succession, forest fires, and change in human population (Tsegaye et al. 2010; Tefera 2011). Bush/shrub covers can be found in a wider range of climates because it is relatively less sensitive to changes in climate (Chuai et al. 2013). The study area experienced an increase in bush/shrub and a decrease in grass and forest (Table 4). Compared to previous studies of other areas, the study area follows the general trend for the changes in vegetation during the given observation period.

Developed and crop land are mainly considered types of land cover associated with human activities. Human activities, such as agriculture, settlements, road construction and commercial development, are important factors that directly affect land-cover changes. Human intervention has more effect on land-cover change than climate change because the effects of climate change take a long period of time to impact land-cover changes (Seto and Shepherd 2009). Both human population and groundwater have decreased in the study area. For example, the population for the study area decreased from 1348 people in 1970 to 678 people in 2009 (US Census Bureau 2010). Groundwater has decreased since the 1970 level. The study area also experienced a decrease in precipitation from $425.5-379.2 \mathrm{~mm}$ but an increase in temperature from $11.0-11.9^{\circ} \mathrm{C}$, which might suggest that the study area climate is gradually moving towards the more arid side of a semi-arid environment. We suspect that a harsher environment for crop production and increased deficit in available water for human activities has already occurred in the study area.

\subsection{CHANGES IN WATER RESOURCES}

The study area hydrological system is characterized as about $93.4 \%$ evapotranspiration, $1.0 \%$ soil water, $5.1 \%$ surface runoff, $0.2 \%$ groundwater discharge. About $0.4 \%$ of the actual precipitation remains as the change in storage. Previous studies on a semi-arid climate (Ragab and Prudhomme 2002; Abdulla et al. 2009) show a similar evapotranspiration pattern whereas the runoff rate is significantly higher than in our study. This difference is likely caused by about $98 \%$ vegetation in the study area whereas previous studies included considerable amounts of developed land, which hindered infiltration and increased surface runoff.

\subsubsection{Surface Runoff}

Surface runoff generally has a similar trend to that of precipitation (Guo et al. 2008). For an urbanized area the variation in surface runoff is greater than the variation in precipitation because developed land (i.e., impervious surface) decreases the rate of infiltration and increases the rate of flow and the volume of surface runoff (Claessens et al.
2006; Hamdi et al. 2011). Previous studies showed a 10 $20 \%$ decrease in surface runoff associated with a $5-10 \%$ decrease in precipitation (Séguis et al. 2004; Jarsjö et al. 2012). Our study area has minimal human impact, as developed land decreased from $1.2-0.6 \%$ over the observation period. This suggests that only about $1 \%$ change in developed land may not be sufficient enough to affect surface runoff controlled by climate.

\subsubsection{Groundwater Discharge}

In general groundwater discharge can be more directly affected by human intervention than by climate change because changes in groundwater respond slowly to climate change (USGCRP 2009). A low amount of precipitation can result in a decrease in surface runoff and the groundwater recharge rate, which eventually leads to a decrease in groundwater discharge (Ferguson and Maxwell 2010). The land-cover change in the study area shows a decrease in the amount of crop and developed land. The study area also experienced a decrease in population from 1348 in 1970 to 678 in 2009 (US Census Bureau 2010). These facts suggest that groundwater discharge in the study area is influenced more by climate change than human activities.

\subsubsection{Soil Water Content}

The soil water content is affected by temperature, precipitation, and land cover (IPCC 2007; Zhou et al. 2011). High temperature leads to an increase in evapotranspiration, which eventually decreases soil water content whereas a high amount of precipitation directly results in an increase in soil water content (USGCRP 2009). An increase in vegetation and a decrease in developed land can have a positive impact on soil water content (Kim and Wang 2007; Hamdi et al. 2011). During the forty years of the study timeframe, the vegetation cover increased from $96.7-97.8 \%$ and the developed land decreased from $1.2-0.6 \%$. The decrease in precipitation of about $11 \%$ was offset by a high proportion of vegetation and a decrease in developed land, which resulted in a decrease in soil water content of about $4 \%$.

\subsubsection{Evapotranspiration}

Evapotranspiration can be increased by high temperatures, wind speed and albedo. Evapotranspiration can be reduced by high humidity (USGCRP 2009). In addition to the above factors, evapotranspiration can also be affected by land cover. Increased vegetation cover increases the rate of evapotranspiration whereas areas that have a large percentage of developed land exhibit decreased evapotranspiration rate (Dahm et al. 2002; Kurc and Small 2004; Peel et al. 2010). IPCC (2007) suggested that the evapotranspiration patterns vary depending on different environments. In 
arid environments evapotranspiration is influenced directly by the amount of precipitation because arid regions have low humidity and low precipitation. Our study area, with a semi-arid climate, shows that the rate of evapotranspiration generally follows the precipitation trend (Fig. 5). However, other factors, such as wind speed, solar radiation, albedo, and humidity, must also be considered to understand the evapotranspiration response rate clearly.

\section{CONCLUSIONS}

This study investigated the climate and land-cover changes impact on water resources in a semi-arid watershed from 1970 - 2009. We selected a semi-arid watershed where human impact is minimal to understand the natural response of water resources to climate and land-cover changes. SWAT simulations were conducted to evaluate the water resource component employing three different land cover data sets representing three different sub-periods: 1970s/1980s, $1990 \mathrm{~s}$, and 2000s. The study area experienced a $0.9^{\circ} \mathrm{C}$ increase in temperature and a $10.9 \%$ decrease in precipitation during the forty recorded years. Compared to previous studies on semi-arid climates the study area had a lower rate of temperature increase and a similar decreasing trend in precipitation. We found that an increase in temperature in the study area was not as significant if the human development factor was removed. Precipitation generally follows a decreasing pattern as with other semi-arid locations. The two predominant land-cover change trends were the conversion of grass and forest lands into bush/shrub lands and developed and crop lands conversion into barren and grass lands. These changes indicate that conversions into barren and grass lands were influenced by a decrease in human activity. It is further suggested that changes in temperature and precipitation affected land-cover changes including the types of vegetation where human intervention is minimal. We noted a $10.2 \%$ decrease in surface runoff, a $10.0 \%$ decrease in groundwater discharge, a $4.1 \%$ decrease in soil water content, and a $10.5 \%$ decrease in evapotranspiration. In the study area surface runoff, groundwater discharge and evapotranspiration generally followed similar trends to that of precipitation when human impact is minimal. The soil water content is relatively sensitive to land-cover change where a decrease in precipitation is offset by the impact of land-cover changes.

Acknowledgements This work was supported by the National Research Foundation of Korea Grant funded by the Korean Government (NRF-2012R1A1A1041589).

\section{REFERENCES}

Abdulla, F., T. Eshtawi, and H. Assaf, 2009: Assessment of the impact of potential climate change on the water balance of a semi-arid watershed. Water Resour. Manag., 23, 2051-2068, doi: 10.1007/s11269-008-9369-y. [Link]

Brümmer, C., T. A. Black, R. S. Jassal, N. J. Grant, D. L. Spittlehouse, B. Chen, Z. Nesic, B. D. Amiro, M. A. Arain, A. G. Barr, C. P. A. Bourque, C. Coursolle, A. L. Dunn, L. B. Flanagan, E. R. Humphreys, P. M. Lafleur, H. A. Margolis, J. H. McCaughey, and S. C. Wofsy, 2012: How climate and vegetation type influence evapotranspiration and water use efficiency in Canadian forest, peatland and grassland ecosystems. Agric. For. Meteorol., 153, 14-30, doi: 10.1016/j.agrformet.2011.04.008. [Link]

Cho, H. and F. Olivera, 2014: Application of multimodal optimization for uncertainty estimation of computationally expensive hydrologic models. J. Water Resour. Plan. Manage., 140, 313-321, doi: 10.1061/(ASCE) WR.1943-5452.0000330. [Link]

Cho, H., D. Kim, F. Olivera, and S. D. Guikema, 2011: Enhanced speciation in particle swarm optimization for multi-modal problems. Eur. J. Oper. Res., 213, 15-23, doi: 10.1016/j.ejor.2011.02.026. [Link]

Chuai, X. W., X. J. Huang, W. J. Wang, and G. Bao, 2013: NDVI, temperature and precipitation changes and their relationships with different vegetation types during 1998-2007 in Inner Mongolia, China. Int. J. Climatol., 33, 1696-1706, doi: 10.1002/joc.3543. [Link]

Claessens, L., C. Hopkinson, E. Rastetter, and J. Vallino, 2006: Effect of historical changes in land use and climate on the water budget of an urbanizing watershed. Water Resour. Res., 42, W03426, doi: 10.1029/2005WR004131. [Link]

Crosbie, R. S., D. W. Pollock, F. S. Mpelasoka, O. V. Barron, S. P. Charles, and M. J. Donn, 2012: Changes in Köppen-Geiger climate types under a future climate for Australia: Hydrological implications. Hydrol. Earth Syst. Sci., 9, 7415-7440, doi: 10.5194/ hessd-9-7415-2012. [Link]

Dahm, C. N., J. R. Cleverly, J. E. A. Coonrod, J. R. Thibault, D. E. McDonnell, and D. J. Gilroy, 2002: Evapotranspiration at the land/water interface in a semi-arid drainage basin. Freshwater Biol., 47, 831-843, doi: 10.1046/j.1365-2427.2002.00917.x. [Link]

Dixon, B. and J. Earls, 2012: Effects of urbanization on streamflow using SWAT with real and simulated meteorological data. Appl. Geogr., 35, 174-190, doi: 10.1016/j.apgeog.2012.06.010. [Link]

Ferguson, I. M. and R. M. Maxwell, 2010: Role of groundwater in watershed response and land surface feedbacks under climate change. Water Resour. Res., 46, W00F02, doi: 10.1029/2009WR008616. [Link]

Fraedrich, K., F. W. Gerstengarbe, and P. C. Werner, 2001: Climate shifts during the last century. Clim. Change, 50, 405-417, doi: 10.1023/A:1010699428863. [Link] 
Guo, H., Q. Hu, and T. Jiang, 2008: Annual and seasonal streamflow responses to climate and land-cover changes in the Poyang Lake basin, China. J. Hydrol., 355, 106-122, doi: 10.1016/j.jhydrol.2008.03.020. [Link]

Guo, S., H. Chen, H. Zhang, L. Xiong, P. Liu, B. Pang, G. Wang, and Y. Wang, 2005: A semi-distributed monthly water balance model and its application in a climate change impact study in the Middle and lower Yellow River basin. Water Int., 30, 250-260, doi: 10.1080/02508060508691864. [Link]

Hamdi, R., P. Termonia, and P. Baguis, 2011: Effects of urbanization and climate change on surface runoff of the Brussels Capital Region: A case study using an urban soil-vegetation-atmosphere-transfer model. Int. J. Climatol., 31, 1959-1974, doi: 10.1002/joc.2207. [Link]

He, B., Y. Wang, K. Takase, G. Mouri, and B. H. N. Razafindrabe, 2009: Estimating land use impacts on regional scale urban water balance and groundwater recharge. Water Resour. Manag., 23, 1863-1873, doi: 10.1007/ s11269-008-9357-2. [Link]

Heo, J., J. Yu, J. R. Giardino, and H. Cho, 2015: Impacts of climate and land-cover changes on water resources in a humid subtropical watershed: A case study from East Texas, USA. Water Environ. J., 29, 51-60, doi: 10.1111/wej.12096. [Link]

IPCC, 2007: Climate Change 2007: Synthesis Report, Contribution of Working Groups I, II and III to the Fourth Assessment Report of the Intergovernmental Panel on Climate Change, IPCC, Geneva, Switzerland, 104 pp. Available at https://www.ipcc.ch/publications_and data/publications_ipcc_fourth_assessment_report_ synthesis_report.htm.

Jarsjö, J., S. M. Asokan, C. Prieto, A. Bring, and G. Destouni, 2012: Hydrological responses to climate change conditioned by historic alterations of land-use and water-use. Hydrol. Earth Syst. Sci., 16, 1335-1347, doi: 10.5194/hess-16-1335-2012. [Link]

Keating, B. A., D. Gaydon, N. I. Huth, M. E. Probert, K. Verburg, C. J. Smith, and W. Bond, 2002: Use of modelling to explore the water balance of dryland farming systems in the Murray-Darling Basin, Australia. Eur. J. Agron., 18, 159-169, doi: 10.1016/S11610301(02)00102-8. [Link]

Kim, D., F. Olivera, H. Cho, and S. A. Socolofsky, 2013: Regionalization of the modified Bartlett-Lewis Rectangular Pulse stochastic rainfall model. Terr. Atmos. Ocean. Sci., 24, 421-436, doi: 10.3319/ TAO.2012.11.12.01(Hy). [Link]

Kim, Y. and G. Wang, 2007: Impact of vegetation feedback on the response of precipitation to antecedent soil moisture anomalies over North America. J. Hydrometeorol., 8, 534-550, doi: 10.1175/JHM612.1. [Link]

Kundzewicz, Z. W., 2008: Climate change impacts on the hydrological cycle. Ecohydrology Hydrobiol., 8, 195-
203, doi: 10.2478/v10104-009-0015-y. [Link]

Kurc, S. A. and E. E. Small, 2004: Dynamics of evapotranspiration in semiarid grassland and shrubland ecosystems during the summer monsoon season, central New Mexico. Water Resour. Res., 40, W09305, doi: 10.1029/2004WR003068. [Link]

Lenihan, J. M., R. Drapek, D. Bachelet, and R. P. Neilson, 2003: Climate change effects on vegetation distribution, carbon, and fire in California. Ecol. Appl., 13, 1667-1681, doi: 10.1890/025295. [Link]

Long, H., G. Tang, X. Li, and G. K. Heilig, G. 2007: Socioeconomic driving forces of land-use change in Kunshan, the Yangtze River Delta economic area of China. J.Environ. Manage., 83, 351-364, doi: 10.1016/j.jenvman.2006.04.003. [Link]

Ma, X., J. Xu, Y. Luo, S. P. Aggarwal, and J. Li, 2009: Response of hydrological processes to land-cover and climate changes in Kejie watershed, south-west China. Hydrol. Process., 23, 1179-1191, doi: 10.1002/ hyp.7233. [Link]

Montenegro, S. and R. Ragab, 2012: Impact of possible climate and land use changes in the semi arid regions: A case study from North Eastern Brazil. J. Hydrol., 434-435, 55-68, doi: 10.1016/j.jhydrol.2012.02.036. [Link]

Moriasi, D. N., J. G. Arnold, M. W. Van Liew, R. L. Bingner, R. D. Harmel, and T. L. Veith, 2007: Model evaluation guidelines for systematic quantification of accuracy in watershed simulations. Trans. ASABE, 50, 885-900, doi: 10.13031/2013.23153. [Link]

Mosbahi, M., S. Benabdallah, and M. R. Boussema, 2014: Sensitivity analysis of a GIS-based model: A case study of a large semi-arid catchment. Earth Sci. Inform., doi: 10.1007/s12145-014-0176-0. [Link]

Peel, M. C., B. L. Finlayson, and T. A. McMahon, 2007: Updated world map of the Köppen-Geiger climate classification. Hydrol. Earth Syst. Sci., 11, 1633-1644, doi: 10.5194/hess-11-1633-2007. [Link]

Peel, M. C., T. A. McMahon, and B. L. Finlayson, 2010: Vegetation impact on mean annual evapotranspiration at a global catchment scale. Water Resour. Res., 46, W09508, doi: 10.1029/2009WR008233. [Link]

Ragab, R. and C. Prudhomme, 2002: Climate change and water resources management in arid and semi-arid regions: Prospective and challenges for the 21st century. Biosyst. Eng., 81, 3-34, doi: 10.1006/bioe.2001.0013. [Link]

Rosenberg, N. J., D. J. Epstein, D. Wang, L. Vail, R. Srinivasan, and J. G. Arnold, 1999: Possible impacts of global warming on the hydrology of the Ogallala aquifer region. Clim. Change, 42, 677-692, doi: 10.1023/A:1005424003553. [Link]

Scanlon, B. R., R. W. Healy, and P. G. Cook, 2002: Choosing appropriate techniques for quantifying groundwater recharge. Hydrogeol. J., 10, 18-39, doi: 10.1007/ 
s10040-001-0176-2. [Link]

Séguis, L., B. Cappelaere, G. Milési, C. Peugeot, S. Massuel, and G. Favreau, 2004: Simulated impacts of climate change and land-clearing on runoff from a small Sahelian catchment. Hydrol. Process., 18, 3401-3413, doi: 10.1002/hyp.1503. [Link]

Seto, K. C. and J. M. Shepherd, 2009: Global urban landuse trends and climate impacts. Curr. Opin. Env. Sust., 1, 89-95, doi: 10.1016/j.cosust.2009.07.012. [Link]

Sharda, V. N., R. S. Kurothe, D. R. Sena, V. C. Pande, and S.P. Tiwari, 2006: Estimation of groundwater recharge from water storage structures in a semi-arid climate of India. J. Hydrol., 329, 224-243, doi: 10.1016/j.jhydrol.2006.02.015. [Link]

Tefera, M. M., 2011: Land-use/land-cover dynamics in Nonno district, central Ethiopia. J. Sustain. Dev. Af., 13, 123-141.

Tsegaye, D., S. R. Moe, P. Vedeld, and E. Aynekulu, 2010: Land-use/cover dynamics in Northern Afar rangelands, Ethiopia. Agr. Ecosyst. Environ., 139, 174-180, doi: 10.1016/j.agee.2010.07.017. [Link]

US Census Bureau, 2010: Census of Population and Housing, American Community Surveys. Available at http:// www.census.gov/prod/www/decennial.html.

USGCRP, 2009: US Global Climate Research Program 2009 Report. Available at http://www.globalchange.gov/.

Wickham, J. D., S. V. Stehman, J. H. Smith, and L. Yang, 2004: Thematic accuracy of the 1992 National LandCover Data for the western United States. Remote Sens. Environ., 91, 452-468, doi: 10.1016/j.rse.2004.04.002. [Link]

Wu, Y., S. Liu, and A. L. Gallant, 2012: Predicting impacts of increased $\mathrm{CO}_{2}$ and climate change on the water cycle and water quality in the semiarid James River Basin of the Midwestern USA. Sci. Total Environ., 430, 150160, doi: 10.1016/j.scitotenv.2012.04.058. [Link]

Xu, C., Y. Chen, Y. Yang, X. Hao, and Y. Shen, 2010: Hydrology and water resources variation and its response to regional climate change in Xinjiang. J. Geogr. Sci., 20, 599-612, doi: 10.1007/s11442-010-0599-6. [Link]

Zhang, L., L. Qin, Z. Yang, J. Xia, and S. Zeng, 2012: Climate change impacts on hydrological processes in the water source area of the Middle Route of the Southto-North Water Diversion Project. Water Int., 37, 564584, doi: 10.1080/02508060.2012.692108. [Link]

Zhang, X., R. Srinivasan, and D. Bosch, 2009: Calibration and uncertainty analysis of the SWAT model using Genetic Algorithms and Bayesian Model Averaging. J. Hydrol., 374, 307-317, doi: 10.1016/j.jhydrol.2009.06.023. [Link]

Zhang, X., R. Srinivasan, and M. Van Liew, 2010: On the use of multi-algorithm, genetically adaptive multi-objective method for multi-site calibration of the SWAT model. Hydrol. Process., 24, 955-969, doi: 10.1002/ hyp.7528. [Link]

Zhou, G., X. Wei, Y. Wu, S. Liu, Y. Huang, J. Yan, D. Zhang, Q. Zhang, J. Liu, Z. Meng, C. Wang, G. Chu, S. Liu, X. Tang, and X. Liu, 2011: Quantifying the hydrological responses to climate change in an intact forested small watershed in Southern China. Global Change Biol., 17, 3736-3746, doi: 10.1111/j.13652486.2011.02499.x. [Link]

Ziegler, A. D., E. P. Maurer, J. Sheffield, B. Nijssen, E. F. Wood, and D. P. Lettenmaier, 2005: Detection time for plausible changes in annual precipitation, evapotranspiration, and streamflow in three Mississippi River sub-basins. Clim. Change, 72, 17-36, doi: 10.1007/ s10584-005-5379-4. [Link] 